\title{
Cartographies of Genocide
}

\author{
Alberto Giordano ${ }^{\mathrm{a}, *}$ \\ ${ }^{a}$ Department of Geography, Texas State University, San Marcos, TX 7866, USA \\ * Corresponding author
}

Keywords: Cartographic design, Maps and propaganda, Genocide, Holocaust

\begin{abstract}
Maps and visual representations in general are powerful tools of propaganda and construction of the "other" that perpetrators of genocide employ in different ways and in different contexts and depending on audience, purpose, and stage of genocide. Maps and visual representations are also powerful tools to denounce genocide and are used by the victims to relate, remember, and communicate their experience. These topics will be discussed in the context of the Holocaust and focusing specifically on cartographic design. The role of propaganda, semiotics, the concept of "myth," and iconography will be briefly discussed to frame the theoretical context of the presentation.
\end{abstract}

These topics are part of a broader research agenda on the geographies and cartographies of genocide that I have been engaged in for several years. In particular, I am interested in how cartography, geography and GIScience may contribute to defining, studying, and understanding past genocides, and, hopefully, help preventing future ones. As the majority of my past and current research has been on the Holocaust, the examples discussed in my presentation are relative to that specific genocide. To start with, it is useful to review and define what genocide is and who its perpetrators are.

Genocide has been defined in various ways. According to the United Nations (1951), genocide means any of the following acts committed with intent to destroy, in whole or in part, a national, ethnical, racial or religious group, as such: (a) killing members of the group; (b) causing serious bodily or mental harm to members of the group; (c) deliberately inflicting on the group conditions of life calculated to bring about its physical destruction in whole or in part; (d) imposing measures intended to prevent births within the group; (e) forcibly transferring children of the group to another group. This definition stresses the physical destruction of the group targeted by direct or indirect methods, such as the prevention of births by members of the group or the forcible transfer of children from the targeted group to another group. Harff and Gurr (1988) highlight the role of the State and the policy dimensions of genocide: "by our definition, genocide... is the promotion and execution of policies by a state or its agents which result in the deaths of a substantial portion of a group." Katz (1994) remarks the fact that it is the perpetrator that defines who the targeted victims and groups: "...the actualization of the intent, however successfully carried out, to murder in its totality any national, ethnic, racial, religious, political, social, gender or economic group, as these groups are defined by the perpetrator, by whatever means."

However defined, genocide is carried out in stages that may vary temporally and geographically, as well as in the methods used to commit it, and this is especially the case when acts of genocide are committed over a long period of time and over a large area, as the Holocaust as well as the Armenian genocide, on which I have also worked, show well. Hampton (1986) has proposed a model of the stages of genocide-later modified and redefined, by Stanton (2013) and others - that identifies eight steps, more or less in succession, that include classification ("us vs them"), symbolization ("Jews", "Germans", "Tutsi", swastikas, yellow stars), dehumanization (one group denies the humanity of members of another group and calls them "vermin," rats," or "cockroaches"), organization (as a group crime, as opposed to an individual act, genocide needs to be organized, usually by the State), polarization (this is when rhetoric is ramped up, legislation is introduced, extremists emerge, and political moderates are silenced), preparation (victims are forced to wear identifying symbols, lists are made, victims separated from rest of population, for example in ghettos), extermination (words such as "extermination" or "cleansing" are typically used since the victims are explicitly defined as not fully humans by the perpetrators), and denial (this is always present and starts as soon as during and immediately after the extermination stage, and can outlive the perpetrators themselves; denial includes the destruction of evidence, the destruction of the reputation and credibility of the survivors or witnesses, the claim that deaths were due to famine, migration, disease or, as in the Armenian genocide, all of the above plus the effects of WW1, and-as an ultimate insult - the blaming of the victims themselves).

Once genocide is defined and its stages are identified, a third element is crucial to its understanding: why people commit genocide. Doing so is needed to determine what role maps play in genocide from the perspective of both perpetrators and victims. Several models have been proposed to try and explain why seemingly normal individuals engage in genocide, and models have even been proposed to estimate the likelihood of genocide happening in a given society at a certain time. Waller's model (2005) is perhaps the most influential and, in my opinion, the most convincing. I will discuss Waller's work in more detail during my presentation; here, let just say that the model identifies "ultimate influences" (human nature) as well as "proximate influences" as the reasons why people commit genocide. Most interesting in the context of my research are the "proximate influences," which include the cultural construction of worldviews, the psychological construction of the "other," and the social construction of cruelty. In turn, these "proximate influences" are historicized, i.e., they take different forms in different places at different times depending on 
the specific context. Thus, the indoctrination of SS members during the Holocaust included collectivistic values, authority orientation, and social dominance (cultural influences); "us vs. them" mentality, moral disengagement, and the blaming of the victims (psychological influences); professional socialization, group identification, and the identification of binding factors for the group (social influences). Maps, and images in general (including posters, paintings, movies and other forms of mass communications), can and do play a role in all of the "proximate stages" in Waller's model. In my presentation, as an illustration and for brevity, I will show examples of psychological proximate influences, including the construction of the "other," and in particular I will discuss strategies for the definition, communication, and mass diffusion of an "us vs. them" mentality, the gradual construction and spreading of "moral disengagement" among the perpetrators, and, also among the perpetrators (but also among the bystanders of genocide), the gradual development of a "blaming the victim" mentality to justify active participation, or at least acquiescence, to genocide. In general, to understand the role maps play in this context it is useful to refer to the literature on propaganda and on semiotics, and cartographers have traditionally written about these topics. Perhaps less studied, although not less useful general and specifically in the context of genocide and the definition of the "other," is an iconographical (or iconological) approach; borrowed from art history, this is an especially complex and difficult technique to apply to the interpretation and study of maps, but a promising one. In my presentation I will touch on semiotics, propaganda, and iconography as well as reference and discuss Roland Barthes and his definition of the concept of "myth," which I believe play a central role, one that overlaps all "proximate influences" as defined above, to explain how maps and images relate to genocide.

In the final part of my presentation, I will show examples of the use of maps by perpetrators and victims of genocide. From the perpetrators' perspective, myth and propaganda work together in the service of the State; crucial to the effectiveness of genocide, propaganda and the creation of myths have to be monopolies of the State or they will not work effectively. Nazi Germany was especially effective and efficient from this point of view, with a body of work that I will introduce that include both images and writings from Nazi leaders and propagandists. Referring back to the stages of genocide discussed above, I will make the case that different cartographic design principles are applied for the first six stages (classification, symbolization, dehumanization, organization, polarization, and preparation) of genocide-as well as the psychological construction of the "other"- as opposed to the seventh (extermination) stage. Interestingly, from the point of view of cartographic design, there is a distinct similarity between the maps and images produced by the victims and those produced by the perpetrators, at least as far as the first six stages of genocide are concerned. As I will show in the presentation, this argument is better made via examples, tables, and direct comparisons of design elements, but to briefly summarize my point, depending on their purpose and audience, genocide maps are intended to be alternatively unambiguous or euphemistic, for the masses or for the military and/or political elites, impressionistic or emotional rather than rational and scientific, for public consumption or for private and secret use. In terms of specific elements of design, it is possible to identify the intended audience, purpose, and genocide stage in terms of the use of muted vs. saturated colors, the presence or absence of a legend, the use or not use of graduated symbols and arrows, the scale of the map, how visual contrast is employed to highlight certain elements, the use of black and white, etc.

As concerns more specifically the seventh stage of genocide-extermination - this is when the application of the methods and tools of scientific cartography become the urgent preoccupation of the perpetrators, as many examples from the Nazi archives prove; hence, the search for accuracy and precision in the representation of places, times, and themes, including the insistence on the exactness of measurements, the standardization of design elements, and in general the teaching and application of clear, unambiguous, and replicable designs and methods to make maps. Briefly put, maps produced for the extermination of the victims are characterized as the triumph of denotation and technology, while in the previous six stages connotation and the creation of "myth" are guiding principles by which maps are designed and produced, and their effectiveness is measured.

In my conclusions, I will remark on the fact that as much as maps (and, by extension and in the present time, GIS) have been used and will continue to be used to commit genocide, they can also be effectively used to counteract and denounce genocide. To do so, one should learn how to exploit propaganda techniques and how to use the theories of semiotics and iconography and the idea of myth to counter-map and resist genocide.

\section{References}

1. Harff, B. and Gurr, T.R. 1988. Toward Empirical Theory of Genocides and Politicides: Identification and Measurement of Cases since 1945. International Studies Quarterly, 32-3:359-371.

2. Katz, S.T. 1994. The Holocaust in Historical Context: Volume 1: The Holocaust and Mass Death before the Modern Age. New York, NY: Oxford University Press.

3. Stanton, G. 1986. The 8 Stages of Genocide. Genocide Watch, online at http://www.genocidewatch.org/aboutgenocide/8stagesofgenocide.html. Last checked on January 7, 2019.

4. Stanton, G. 2013. The Ten Stages f Genocide. Genocide Watch, online at http://www.genocidewatch.org/genocide/tenstagesofgenocide.html. Last accessed on 7 January, 2019.

5. United Nations General Assembly Resolution 260, Convention on the Prevention and Punishment of the Crime of Genocide. Adopted by the United Nations General Assembly on 9 December 1948 effective on 12 January 1951.

6. Waller, J 2005. Becoming Evil: How Ordinary People Commit Genocide and Mass Killing. New York: Oxford University Press. 